\title{
Biological Control Agents for Suppression of Post-Harvest Diseases of Potatoes: Strategies on Discovery and Development
}

\author{
Patricia J. Slininger and David A. Schisler \\ National Center for Agricultural Utilization Research, \\ United States Department of Agriculture, Agricultural Research Service, Peoria, IL \\ United States of America
}

\section{Introduction}

As used in plant pathology, the term "biological control" or its short form "biocontrol" commonly refers to the decrease in the inoculum or the disease-producing activity of a pathogen accomplished through one or more organisms, including the host plant but excluding man (Baker, 1987). Biological control of plant pathogens naturally occurs at some level in all agricultural ecosystems, sometimes to a degree where symptoms of disease are noticeably reduced. Thousands of potential microbial biocontrol agents have been isolated from agricultural fields and crops during research over the last 80 years, yet only a few are in commercial use. Recently, public health and safety concerns about the environmental impact of chemical pesticides have led to consideration of biological control as a natural approach to maintaining crop health. Despite environmental incentives and strong research efforts, commercialization of biocontrol agents has been slow to evolve. The momentum of the chemical industry is difficult to shift, and fermentation processes tend to be more expensive to operate than synthetic chemical processes. Yet there is a demand for biological control products, especially in the organic and agricultural niche markets, where there is no efficient chemical competitor. Indeed, the tide has been turning and a recent story in Chemical and Engineering News (Reisch, 2011) has indicated that during the last decade, the growth in sales of biological pest control agents has significantly outpaced that of chemicals. However, given this market demand, the fundamental methods of economical large-scale production and application of biological control agents are still lacking and need to be developed. Many aspects of biocontrol agent production and development represent untrodden territory in the progression of industrial fermentation technology beyond its well-established food and pharmaceuticals niche. Distinguishing them from traditional fermentation products, biocontrol agents must not only be produced in high yield but must also meet the following quality criteria: high (near 100\%) retention of cell viability with maintenance of crop compatibility and consistent bioefficacy during several months of storage. 
This article will focus on the control of post-harvest fungal pathogens, which present unique opportunities but also challenges. Though accurately determining the extent of losses is difficult and few reports are available, it has been estimated that post-harvest decay accounts for an approximate 25\% loss of fresh commodities (USDA, 1965). Biological control using microbial antagonists can be an appropriate tool for managing post-harvest disease problems, especially in crops which are stored under controlled temperatures and high relative humidities. Such controlled storage environments represent a luxury not found when attempting to introduce microbial biological control agents into the comparatively harsh, variable environments found at the infection courts of fungal pathogens of field-grown plants. In recent years, a considerable research attention has focused on biologically controlling rots of fruits post harvest (Janisiewicz, 1988, 1991, 2002). In this chapter, research examples will be reviewed to illustrate the challenges and strategies of developing processes to manufacture and deliver biological agents for post-harvest potato disease control. Concepts to be covered will include the following: market opportunities, choosing pathosystems for biological control, enrichment techniques to enhance new strain discovery, strategies for ranking strains for commercial suitability, mode of action, production considerations, market-broadening functionality, co-cultivation of strains as the next generation biocontrol product, highthroughput screen concept for optimizing biocontrol agent performance from production to delivery, remaining knowledge gaps, and future investigations.

\section{Opportunities and barriers for biopesticides on post-harvest potatoes}

Market success is most likely to occur if the biological control agent is developed to combat pest problems which have no chemical pesticide solution or which exist in situations where chemical applications are prohibited. For example, in the U.S., organic farming is the fastest growing sector of agriculture. Higher commodity prices for these products and regulations restricting the use of chemical pesticides improve the chances for successful commercialization of natural biological tools in these markets (Behle et al., 1999). Once effectiveness is established in this sector of production, the transition to other sectors could follow.

Currently, a major incentive favoring the development of biopesticides is the ease of federal registration in the United States. The Environmental Protection Agency (EPA) has established a Biopesticide Pollution and Prevention Division (BPPD) to manage accelerated registration of biopesticides. In the mid 1990's, the average duration for registration of a biopesticide was 12 months compared with 36 months for all new chemical pesticide registrations (Medugno et al., 1997), and the cost of registration of a chemical was often more than eight times that of a biological (Woodhead et al., 1990). However, despite regulatory incentives, relatively few biological control agents have reached the market place, often due to one or more of the following pitfalls: (a) poor choice of pathosystem for biological control; (b) relatively few candidate microorganisms available for testing; (c) microbes are selected based on the results of an assay that does not replicate field conditions; and (d) the amenability of microbes to commercial development is excluded as a selection criterion.

\section{Fusarium dry rot - An appropriate pathosystem for biological control}

Characteristics of a pest problem, or "pathosystem," suitable to a biological control approach include: exploitable weakness(es), existence in an environment favorable to 
introduced antagonists, availability of few or no control options, and causative of significant economic loss to agriculture. Our experience on discovery and development of biological control agents first began with the need to find an alternative to thiabendazole (TBZ) for the biological control of Fusarium dry rot, an important post-harvest disease of potatoes. Dry rot is caused primarily by Gibberella pulicaris (Fr.:Fr.) Sacc. (anamorph: Fusarium sambucinum Fuckel) (Boyd, 1972). The fungus is a serious pathogen in potato tuber storages and can produce trichothecene toxins (Desjardins \& Plattner, 1989) implicated in mycotoxicosis of humans and animals. Yield losses attributed to dry rot in storage range from 6 to $25 \%$ with up to $60 \%$ of tubers affected in some cases (Secor \& Salas, 2001). Measures for controlling this disease in storage are limited. Resistance to TBZ, the only chemical registered for postharvest use on tubers for human consumption, is now widespread among strains of $G$. pulicaris (Desjardins et al., 1993; Hanson et al., 1996; Kawchuk et al., 1994; Secor et al., 1994). High levels of resistance to Fusarium dry rot in potato cultivars and breeders' selections are not apparent (Pawlak et al., 1987) and all commonly grown potato cultivars are susceptible (Reiners \& Petzoldt, 2004). Therefore, the potential for damage is high enough to justify the economic risk of developing a biological control agent for prevention of dry rot disease losses. A major weakness of the etiology of this pathogen is that it requires a wound in order to infect, and tubers are able to heal wounds in less than 2 weeks in storage. Additionally, the pathogen operates in an environment that is favorable to introduced antagonists in that tuber storage temperatures are uniform and relative humidities are high $(>90 \%)$, a feature true for many post-harvest pathosystems.

\section{Discovery of biocontrol agents amenable to commercial production}

Main objectives driving the development of our techniques to discover beneficial biological control agents for dry rot suppression involved two phases: (1) rapid screening of large numbers of microbes using enrichment techniques to concentrate desirable populations and a crop-relevant bioassay to identify useful biological control agents; (2) rating potentially useful agents based on the challenges of manufacturing and delivery.

\subsection{Rapid isolation from large populations via enrichment techniques}

Ideally biological control agent isolation should begin in areas where biological control is naturally occurring in the field, as opposed to areas where it is not. Evaluating a maximal number of putative biocontrol agents increases the chance of discovering an effective strain. Isolating prospective biocontrol agents from appropriate tissues and under appropriate environmental conditions helps to insure that the microbial antagonists isolated will be well adapted to survival and activity on the specific tissues requiring protection. Application of these concepts resulted in our rapid isolation of 18 putative biological control agents for suppression of Fusarium dry rot. The steps of our method are illustrated in Figure 1 (Schisler \& Slininger, 1994). Specifically, gamma irradiation-sterilized field soil samples were first enriched with potato tuber periderm, inoculated with a small amount of field soil obtained from potato fields with low dry rot disease incidence, and incubated for 1 week at $15^{\circ} \mathrm{C}$. The microorganisms most adept at rapid growth on the nutrients found in potato periderm and at wound sites would make up the majority of microbes in each recolonized soil sample. Next, conidia of G. pulicaris were added to the microbially recolonized soils, and 2 days later, aqueous soil pastes of each soil were applied to wounded potato tubers to initiate a realistic disease bioassay. After incubation 4 weeks at $15^{\circ} \mathrm{C}$, tubers were scored for 
dry rot disease development. Those wounds that developed inconsequential disease were highly likely to contain microbial communities able to survive on potato periderm, to colonize potato tissue, and to suppress disease development. Consequently, clear wounds were excavated and dilution plated on nonselective media that allowed growth of bacteria, fungi, actinomycetes, and yeasts to allow isolation of broad microbial diversity. Using this process, over 350 isolated colonies were obtained from clear wounds receiving microbial communities transferred via live soil samples from 35 locations of low disease incidence. To screen out only those strains participating in dry rot suppression, each isolate was suspended in buffer with conidia of the pathogen and inoculated to a fresh potato wound. After 3 weeks at $15^{\circ} \mathrm{C}$, tubers were checked for the presence of disease and only 18 of the 350 isolates demonstrated significant dry rot suppression relative to controls inoculated only with pathogen. It is notable that all of the 18 beneficial isolates were identified as Gramnegative bacteria.

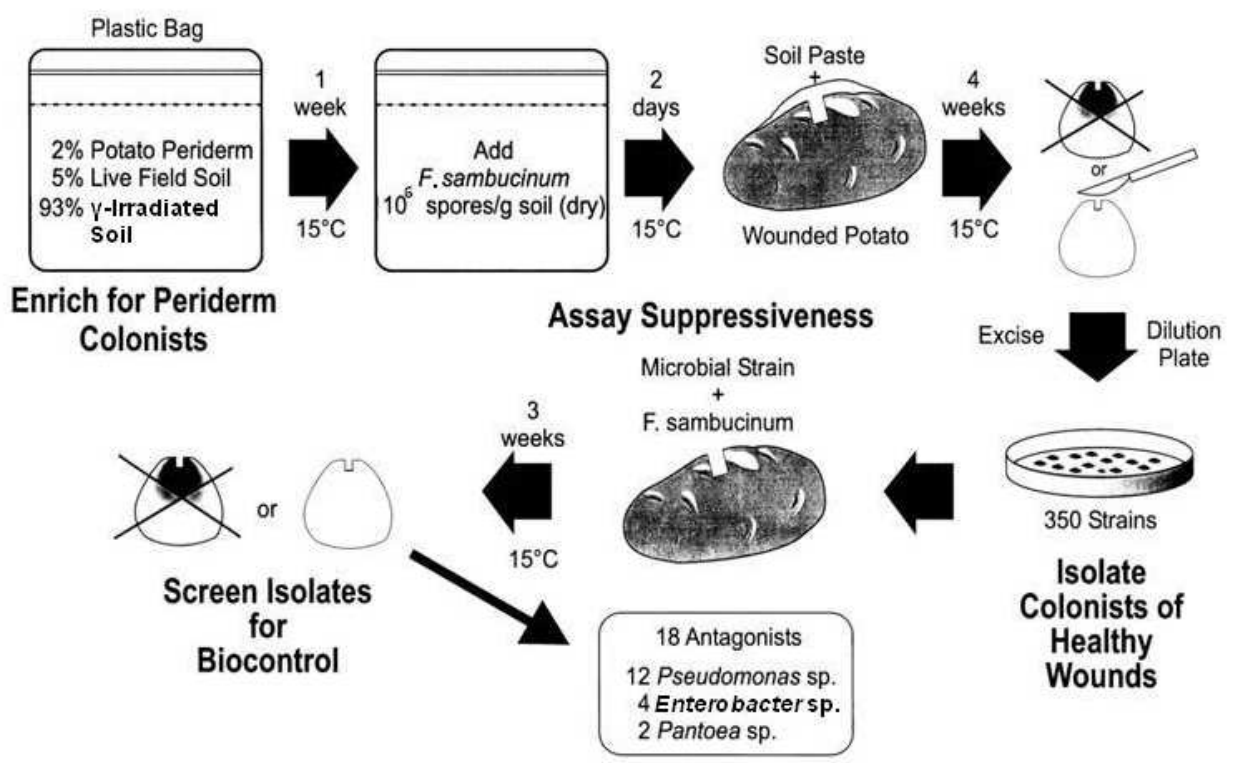

Fig. 1. Isolation of microbial antagonists effective in suppressing Fusarium dry rot of potatoes (Schisler \& Slininger, 1994).

\subsection{Screening potential strains for commercial suitability}

Researchers involved in the discovery and development of biological control agents may speed biocontrol agent commercialization by using an end-process-oriented screening approach. This concept refers to designing the screen to select strains based on their performance under conditions simulating key challenges typically posed by mass production (Standbury \& Whitaker, 1984). Since the U.S. industry standard for the manufacture of microbial products is batch liquid cultivation, it was chosen as the method of producing the 18 dry rot antagonistic bacteria for further evaluations. Compared with 
synthetic chemical processes, fermentation processes are relatively expensive, a circumstance which has largely limited the exploration and development of biotechnology to the food and pharmaceutical fields (Van Brunt, 1986). Primary cost factors include raw materials, utilities, labor, and capital investment. Since the culture medium is central to fermentation process design and economics, our selection of the most commercially promising strains was based on their ability to grow rapidly and to high yield on a variety of liquid culture media and then to accomplish biocontrol upon harvest and delivery to potatoes. These considerations were combined to select efficacious dry rot antagonists that could be produced with reduced fermentor volume and cultivation process costs. The steps in this screening process are illustrated in Figure 2 based on the procedure of Slininger et al. (1994).

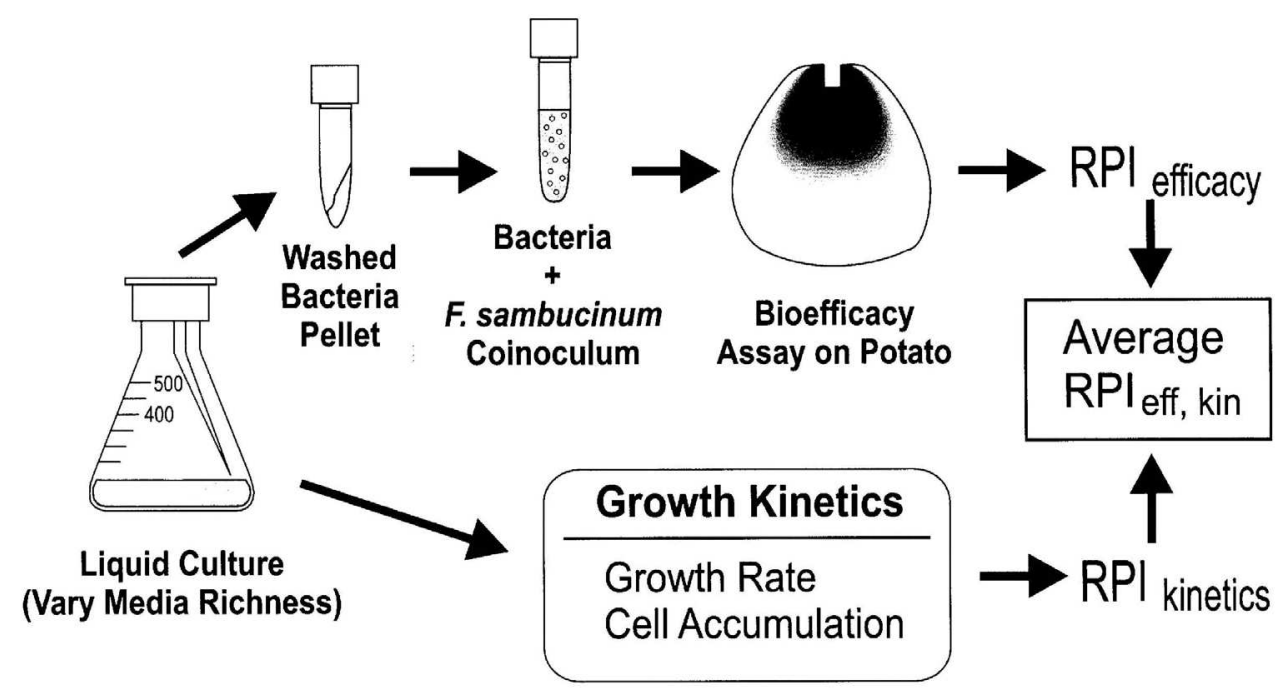

Fig. 2. Two dimensional liquid culture method of ranking commercial development potential of biological control strains using relative performance index, RPI (Slininger et al. 1994).

Strains with the nutritional flexibility to grow rapidly and achieve large bioefficacious populations were sought by challenging with glucose media ranging in richness from a minimal medium (with nitrogen supplied by urea) to a semidefined complete medium (with casamino acids and growth factors) to an undefined medium (with added yeast extract, peptone, and tryptone). Such flexibility is very desirable because it allows process optimization choices to be driven by materials cost and convenience rather than by the fastidiousness of the microorganism. Consistent with utilities considerations, shake-flask cultures were provided a low oxygen transfer coefficient $\left(\mathrm{K}_{1} \mathrm{a} \sim 0.5 \mathrm{~min}^{-1}\right)$ and moderately warm temperature $\left(25^{\circ} \mathrm{C}\right)$ without $\mathrm{pH}$ control since most soil-borne microorganisms survive and grow with temperatures ranging from 7 to $30^{\circ} \mathrm{C}$ and within a fairly broad $\mathrm{pH}$ range 
from 5 to 8 . Harvested bacteria were then bioassayed using the wounded potato assay described above to assess efficacy.

For each bacterium, a relative performance index (RPI) was calculated based on each kinetic parameter, such as specific growth rate and cell yield. Given parameter values normally distributed across the isolate group tested, the value of $F=\left(X-X_{\text {avg }}\right) / s$ ranges from -2 to +2 . Here, $X$ designates a single value observed per bacterium, and $X_{\text {avg }}$ and $s$ are the average and standard deviation, respectively, of all values observed for the isolate group. Using the formula RPI $=(F+2) \times 100 / 4$, data corresponding to each parameter type were translated to dimensionless indices, scaled from 0 to 100, which reflected relative bacterial performance. For a given production trial, overall relative kinetic performance indices were calculated for each bacterium: $R P I_{\text {kinetics }}=\left(R P I_{\text {growth rate }}+R P I_{\text {cell yield }}\right) / 2$. Similarly, a relative performance index based on biocontrol efficacy was calculated for each bacterium using log (disease rating) data: $\mathrm{RPI}_{\text {efficacy }}=(2-\mathrm{F}) \times 100 / 4$. Note that the term $(2-\mathrm{F})$ is used instead of $(2+\mathrm{F})$ because efficacy improves as disease rating decreases. Thus, $\mathrm{RPI}_{\text {efficacy }}$ and $\mathrm{RPI}_{\text {kinetics }}$ are provided a common dimensionless 0-100 scale that allows both data types equal weight in the overall performance assessment. As a result of this screening method (Fig. 2), referred to as "two-dimensional liquid culture focusing" (2DLCF), the 18 bacterial dry rot antagonists were ranked with respect to potential for commercial development, 6 strains being in statistical significance group A (Table 1).

Dogma calls for screening the efficacies of prospective biocontrol agents grown under conditions as similar as possible to what is expected to be encountered in nature. Thus, "promising" isolates have been traditionally selected based on efficacy following growth on solidified media. Only after extensive laboratory, greenhouse, and field tests of these promising isolates has mass production in liquid culture become a concern. Indeed our data have shown that the traditional one-dimensional screen based on bioefficacy of agargrown isolates selects a different set of top-performers than does the commercial processoriented 2DLCF screen, and the traditional screen is likely to miss selection of the most commercially useful biocontrol agents because it fails to recognize that liquid culture competency varies widely among microbes. Our experiments have illustrated this by showing that the top-performing strains selected via the 2DLCF screen were often ranked the worst performing strains in the traditional one-dimensional screen of one-fifth tryptic soy broth agar-grown isolates (Table 1) (Slininger et al., 1994). If our goal is to develop bacteria with a commercial future as biocontrol agents, then early screening strategies must reflect the production requirements of the commercial setting. Since liquid culture is the industrial standard for microbial production, liquid cultivation should be the method of biocontrol agent production during early screening. In addition, a two-dimensional assay examining liquid culture growth kinetics as well as product biocontrol efficacy is needed because, our results have shown that isolate performance ranking based on kinetics is not necessarily reflective of the performance ranking based on the biocontrol efficacy, yet both of these features are critical to process economics and commercial success. The processes shown in Figures 1 and 2 have resulted in identification of strains able to suppress dry rot under commercial storage conditions (Slininger et al., 1996a; Schisler et al., 1998a; Schisler et al. 2000b), and recently have been similarly applied to find additional novel bacterial strains with commercial potential for post-harvest biocontrol of pink rot (Adiyaman et al., 2011). 


\begin{tabular}{|c|c|c|c|c|c|c|}
\hline \multirow{2}{*}{$\begin{array}{l}\text { Isolate } \\
\text { number } \\
\text { (NRRL-) }\end{array}$} & \multicolumn{2}{|c|}{$\mathrm{RPI}^{1}$} & \multirow{2}{*}{$\begin{array}{l}\text { Overall² } \\
\text { RPI }_{\text {Eff.Kin }}\end{array}$} & \multirow{2}{*}{$\begin{array}{c}\text { Commercial } \\
\text { potential } \\
\text { group }^{2}\end{array}$} & \multicolumn{2}{|c|}{ Rank $^{3}$} \\
\hline & Efficacy & $\begin{array}{l}\text { Growth } \\
\text { kinetics }\end{array}$ & & & & $n k^{3}$ \\
\hline B-21050 & 67.3 & 65.0 & $66.2 \pm 4.9$ & $\mathrm{~A}$ & 1 & (18) \\
\hline B-21128 & 66.3 & 64.9 & $65.6 \pm 5.6$ & A & 2 & (13) \\
\hline B-21133 & 67.2 & 62.3 & $64.8 \pm 3.6$ & A & 3 & (11) \\
\hline B-21134 & 66.3 & 60.3 & $63.3 \pm 4.4$ & A & 4 & (15) \\
\hline B-21132 & 56.9 & 69.4 & $63.1 \pm 5.6$ & $\mathrm{AB}$ & 5 & (14) \\
\hline B-21102 & 62.1 & 60.8 & $61.4 \pm 7.4$ & $\mathrm{ABC}$ & 6 & (16) \\
\hline B-21136 & 58.9 & 57.6 & $58.2 \pm 6.9$ & $\mathrm{BC}$ & 7 & $(8)$ \\
\hline B-21101 & 56.9 & 58.8 & $57.9 \pm 4.9$ & $\mathrm{BC}$ & 8 & (11) \\
\hline B-21103 & 58.4 & 55.7 & $57.0 \pm 4.4$ & C & 9 & (5) \\
\hline B-21053 & 59.2 & 54.2 & $56.7 \pm 5.7$ & C & 10 & (6) \\
\hline B-21135 & 58.7 & 53.8 & $56.2 \pm 6.0$ & C & 11 & (17) \\
\hline B-21129 & 53.0 & 56.5 & $55.1 \pm 11.6$ & $\mathrm{CD}$ & 12 & $(8)$ \\
\hline B-21104 & 63.2 & 35.9 & $49.5 \pm 10.5$ & $\mathrm{DE}$ & 13 & (4) \\
\hline B-21048 & 47.1 & 45.4 & $46.2 \pm 11.1$ & $\mathrm{DE}$ & 14 & (1) \\
\hline B-21137 & 42.8 & 46.7 & $44.7 \pm 11.5$ & $\mathrm{DE}$ & 15 & (6) \\
\hline B-21051 & 60.9 & 25.1 & $43.0 \pm 12.2$ & E & 16 & (1) \\
\hline B-21105 & 38.4 & 28.3 & $33.3 \pm 7.1$ & F & 17 & (10) \\
\hline B-21049 & 31.2 & 23.8 & $27.5 \pm 9.6$ & F & 18 & $(1)$ \\
\hline
\end{tabular}

${ }^{1} \mathrm{RPI}_{\text {ffficacy }}$ and RPIKinetics each indicate the average of six RPI values determined from two independent productions of cells on minimal defined, semi-defined, and undefined liquid media.

${ }^{2}$ Commerical potential groupings were arrived at by applying a two-tailed $t$ analysis to determine the $95 \%$ confidence intervals associated with each mean RPI Eff,Kin as indicated by \pm values. Means that are not significantly different are designated with the same group letter.

${ }^{3}$ Numbers in parenthesis indicate rank based on traditional screen of efficacy of one-fifth trypticase soy agar-grown antagonists.

Table 1. Use of relative performance indices (RPI) to accomplish a two-dimensional assessment of isolate commercial potential based on growth and efficacy of cells produced in liquid culture (Slininger et al. 1994).

\subsection{Multi-dimensional screens to assess commercial potential and robustness}

The concept of early commercial-process-oriented screening brings us closer to rapid development of marketable biocontrol agents; however, it is likely that liquid cultivation of biocontrol agents will be followed by formulation, drying, storage, and reconstitution prior to potato application. These steps are necessary to preserve cells for convenient storage and handling in the time between production and application, and represent other features or "challenges" that could be built into an expanded multi-dimensional strategy for selecting the most commercially promising strains. Furthermore, in the natural potato storage environment, many different strains of Fusarium sambucinum pathogen are present to challenge biocontrol strains, and in addition, the biocontrol agent will be expected to perform well on many different potato cultivars, different crop field histories, and different wound environments. Schisler et al. (2000) examined performance variability as a function of pathogen and cultivar, and in addition to nutritional flexibility to support robustness, biocontrol strains with better overall performance against multiple strains of pathogen on 
multiple cultivars could be selected using the dimensionless relative performance index concept. The ability of biocontrol agents to solve multiple pest control problems is another potential screening dimension. For example, our dry rot antagonistic bacteria have also been shown to be able to suppress late blight (Slininger et al., 2007), pink rot (Schisler et al. 2009), and sprouting of stored potatoes (Slininger et al., 2000, 2003). The ability to expand the market to multiple pest control applications is expected to enhance commercial development potential of a given biocontrol product and is a recurring theme influencing the progression of our research as will be discussed at various points later in this account.

\section{Bioautography as a screen for the presence of antibiotic production}

A variety of potential mechanisms have generally been proposed to be involved in the biological control of plant diseases, including antibiosis, induced disease resistance, competition, parasitism, and predation. Works by Fravel (1988), Huang (1991), Loper \& Buyer (1991), Schisler (1997), and Wilson et al. (1994) are useful starting points for information on mechanisms of biological control and microbial interactions potentially of relevance to dry rot disease development. Antibiosis, induced disease resistance, and competition are all possible mechanisms of control for any of our most effective strains of bacteria. However, with regard to mode of action, our studies have focused on the influence of microbial metabolites on G. pulicaris. In petri plate assays against the dry rot pathogen, G. pulicaris, our 18 bacterial cultures showed varying degrees of inhibition of fungal growth. When extracts from liquid cultures were tested by thin-layer chromatography-bioautography (TLC-BA), a useful technique which correlates antimicrobial activity with the presence of antibiotics (Lazarovits et al., 1982; Homma \& Suzui, 1989), all of the cultures tested were shown to produce at least one compound which inhibited the growth of G. pulicaris (Burkhead et al., 1995).

Antifungal metabolites from Enterobacter cloacae strain S11:T:07 NRRL B-21050, which was highly ranked by the 2DLCF procedure (Table 1, Figure 2), have been isolated from Sabouraud maltose broth culture and identified as phenylacetic acid (PAA), indoleacetic acid (IAA), tyrosol (TSL), and tyrosol acetate, which are recognized to be derived from aromatic amino acids (Burkhead et al., 1998; Slininger et al., 2004). Consequently in later experiments when these compounds were assayed in cultures of strain S11:T:07 (B-21050) grown in three different growth media, it was not a surprise to learn that relative composition of the antifungal compounds produced varied as the culture nutrition, especially amino acid composition, was varied. Antifungal and sprout regulatory bioactivities of these compounds (alone and in combination) were further investigated using our wounded potato assay of dry rot suppressiveness and a cored potato eye assay of sprout inhibition. Assay results showed the antifungal activity of IAA, PAA, and TSL to suppress dry rot infection of wounded potatoes and indicated optimal efficacy when all three metabolites were applied in combination. Furthermore, dosages of IAA resulting in disease suppression, also resulted in sprout inhibition. These results suggest the potential for designing culture production and formulation conditions to achieve a dual purpose biological control agent able to suppress both dry rot and sprouting (Slininger et al., 2004).

\section{Expanding the available market with broad spectrum biological control}

The observation of many antifungal compounds per each dry rot suppressive isolate and the finding of diverse functional activities ranging from antifungal antibiotics to plant 
regulatory hormones of isolated antifungal compounds suggested the fruitfulness of exploring the spectrum of use as a means of improving the market draw for our biological control agents.

\subsection{Sprout inhibition}

Current practices for reducing sprouting in storage could also benefit from microbial alternatives. Because of processing demands, over $54 \%$ of the annual potato harvest must be stored at $7^{\circ}$ to $13^{\circ} \mathrm{C}$, a temperature range above that needed for ideal sprout control (ASAE, 1990). Chemical sprout inhibitors are applied to over $50 \%$ of the potato harvest to extend storage time. The potato industry has become very dependent on CIPC (1-methylethyl-3chlorophenylcarbamate) as the most efficient sprout inhibitor with fewest detrimental sideeffects on process potato quality (Lewis et al., 1996). However, recently, the tolerance for residues of CIPC has been reduced to $30 \mathrm{mg} / \mathrm{kg}$ (EPA 738-R-96-023, 1996) because of CIPC's persistence in the environment and potato tissue and concerns about its toxicity (Mondy et al., 1992). In the U.S.A., CIPC is the only synthetic chemical registered for post-harvest sprout control of stored potatoes, and it is the most widely used sprout inhibitor worldwide. Due to environmental and health safety concerns, the use of CIPC has become more restricted--opening a potential market for alternative sprout control methods. Consequently, six of our bacteria strains, exhibiting superior dry rot suppressiveness in previous research, were grown in two different liquid culture media and sprayed on Russet Burbank potatoes to assay sprout suppresiveness (Slininger et al., 2000, 2003). In growth chamber and pilot experiments repeated at two storage sites in two successive years, all six isolates demonstrated significant sprout control capabilities when applied after growth on at least one of the culture media supplied. Of the six strains tested, Pseudomonas fluorescens S11:P:12 (NRRL B-21133) and two strains of Enterobacter sp., S11:T:07 (NRRL B-21050) and S11:P:08 (NRRL B-21132), exhibited highest relative performance levels with sprout control being statistically similar to that of 16.6 ppm CIPC thermal fog after 4-5 months storage.

\subsection{Late blight}

Several of our top six dry rot suppressive strains have now also been found to significantly reduce late blight infection of stored potatoes (Slininger et al., 2007). Consistent with our observations of indoleacetic acid (IAA) as a major antifungal product produced by one of our dry rot suppressive strains (Slininger et al., 2004), Martiniez Noel et al. (2001) also previously showed that IAA attenuates disease severity in potato-Phytopthora infestans interactions and inhibits pathogen growth in vitro. Phytopthora infestans, the causative agent of the potato late blight disease, infects tubers through eyes or wounds, primarily via zoospores washed into soil from sporangia on infected leaves. Harvested tubers can become infected during washing (Fairclough et al., 1997) and during storage and handling (Lambert et al., 1998). Phytopthora infestans is considered to be the most significant pathogen of the crop worldwide (Fry et al., 2001) and historically was the cause of the Great Potato Famine of the late 1840's. The introduction of US-8 genotypes of $P$. infestans has coincided with an increase in severity of potato late blight in North America. As alternatives to chemical fungicides, our 18 bacterial strains patented as biological control agents of both sprouting and Fusarium dry rot were cultivated in 3 liquid media and screened in wounded potato bioassays for their ability to suppress late blight incited by P. infestans (US-8, mating type A2) (Slininger et al., 2007). Washed or unwashed stationary-phase bacteria were mixed with 
fungal zoospores to inoculate potato wounds. One-fifth of the 108 BCA treatments screened, reduced late blight by $25-60 \%$, including among other strains Pseudomonas fluorescens S22:T:04 (showing most consistency), P22:Y:05 (NRRL B-21053), S11:P:12 and Enterobacter cloacae S11:T:07, the later known to produce IAA. Small-scale pilot testing of these four strains, alone and in combination, was conducted under conditions simulating a commercial application. All four treatments significantly reduced disease; and unwashed bacteria outperformed those washed free of culture broth, indicating a role of metabolites such as IAA. Disease suppression ranged from 35\% up to $86 \%$ the first test year and from 35 to $91 \%$ the second year. Highest overall performance rankings significantly above the control were achieved by the following strains in culture broth: four-strain mix $>$ P. fluorescens S22:T:04 > P. fluorescens S11:P:12. Combined with previous demonstrations of dry rot and sprout suppression, the consistent late blight control by these strains and strain mixtures suggests the commercial utility of a single treatment for broad spectrum suppression of post-harvest potato diseases and sprouting.

\subsection{Pink rot}

Pink rot disease occurs in potato growing regions around the world and is caused primarily by the oomycete Phytophthora erythroseptica Pethybr. Losses of over $50 \%$ of the total harvest can result from tuber contamination by either pink rot or late blight (Secor \& Gudmestad, 1999). All underground portions of potato plants can be infected. Root and stem infections can result in plant wilting and death. Though some evidence indicates that there is limited genetic diversity in North American isolates of P. erythroseptica (Peters et al., 2005), infections initiated after tuber harvest are difficult to control. Most commercially grown potato cultivars in Canada and the United States are susceptible to pink rot and breeding efforts against this disease have been minimal (Peters et al., 2004). Mefenoxam, a phenylamide fungicide that formerly was effective in reducing the disease in storage, has lost much of its effectiveness (Taylor et al., 2006) due to widespread genetic resistance (Taylor et al., 2002) and the stability of the resistance (Abu-El Samen et al., 2005). The use of various salts (Mills et al., 2005), foliar applications of phosphorous acid (Johnson et al., 2004) and the oomycete fungicides "zoxamide" and phosphite (Miller et al., 2006) have reduced symptoms of $P$. erythroseptica on tubers. Additional disease reduction technologies are still needed for organic markets and to deter the development of resistance to chemical fungicides. Tubers generally become infected in the field via stolons previously infected by germinating oospores (a thick-walled spore resulting from sexual recombination) but zoospores (motile, asexually produced spores) or encysted zoospores of the pathogen also can infect tuber eyes, lenticels and cracks and cuts that result from tuber harvesting operations--infection courts theoretically protectable using microbial antagonists. Therefore, 10 of our bacterial antagonists that reduce Fusarium dry rot, late blight, and/or sprouting in storage were assayed for efficacy against pink rot on tubers of cultivars Russet Burbank and Russet Norkotah (Schisler et al., 2009). Antagonist strains were grown in a semidefined liquid medium, diluted to $\sim 3 \times 10^{8} \mathrm{cfu} / \mathrm{ml}$, individually combined with zoospores of $P$. erythroseptica, and used to inoculate shallow puncture wounds on tubers. Data from full factorial experimental designs with 10 levels of antagonist, 2 levels of cultivar, and 2 levels of inoculum age after inducing zoospore liberation from sporangia indicated that all factors influenced the size of pink rot lesions that developed internally around wound sites $(P \leq$ 0.05). In two different sets of experiments, Enterobacter cloacae strain S11:T:07 reduced lesion size more than the other antagonists (19\% and 32\% reduction versus the control) though 
Pseudomonas fluorescens S11:P:14, Pseudomonas sp. S22:T:04, and Enterobacter sp S11:P:08 also significantly reduced disease. Lesion size was greater on Russet Norkotah than Russet Burbank tubers (42.3 and $26.5 \mathrm{~mm}$, respectively), but cultivar did not influence antagonist performance.

\section{Co-cultivation of strains - The next generation}

As reviewed above, Pseudomonas fluorescens strains S11:P:12, P22:Y:05, and S22:T:04 and Enterobacter cloacae strain S11:T:07 have been documented as top strains to suppress four important storage potato maladies-dry rot, late blight, pink rot, and sprouting. These strains are known to differ from one another in their range of antibiotic production, substrate utilization, oxygen requirement, and growth temperature optima. They are also known to differ from one another in ability to inhibit sprouting or suppress disease on various potato cultivars and when incited by various pathogens. The variety of characteristics possessed by the individuals suggests that the successful strain mixtures are likely to be more resilient and more apt to provide individuals amenable to colonize potato wounds despite the variety of environments and pathogen strains encountered. Indeed, our previous experimental results have shown that certain strain pairs applied in combination allow greater dry rot suppression than do individual strains (Schisler et al., 1997). In subsequent laboratory and field trials, we observed that formulations containing multiple strains of our dry rot antagonists performed more consistently than individual strains did when subjected to 32 storage environments varying in potato cultivar, harvest year, potato washing procedure (microflora exposure), temperature, and storage time (Slininger et al., 2001). Successful biocontrol strain mixtures often contained both Enterobacter cloacae and Pseudomonas fluorescens strains. Several other research groups have reported that mixtures of strains can enhance and/or improve the consistency of biological control (among these, Pierson \& Weller, 1994; Duffy \& Weller, 1995; Duffy et al., 1996; Janisiewicz, 1996; Leeman et al., 1996; Guetsky et al., 2001; Krauss \& Soberanis, 2001; Hwang \& Benson, 2002; Schisler et al., 2005; Cruz et al., 2006). Thus, the formulation of strain mixtures has the potential to provide better, more consistent disease control than single strain formulations. Achieving consistent efficacy at each application represents a key advancement toward commercialization of any biocontrol product. However, despite the apparent advantages of applying strain mixes, the disadvantages for the manufacturer are capital costs, operation, maintenance, registration, and management of a different fermentation for each strain used in a mix. A potential way around this obstacle is to co-culture the strains together in one fermentor. To pursue the co-culture concept, we explored the level and consistency of pest control achievable on post-harvest potatoes with the four top multi-functional biological control agents Pseudomonas fluorescens strains S11:P:12, P22:Y:05, and S22:T:04 and Enterobacter cloacae S11:T:07 (Slininger et al., 2010b). The four bacteria were applied to potatoes in the following formats: a) as co-cultures of strains, i.e. multiple strains grown together in a single culture, b) as individual strains grown separately in pure cultures, and c) as blends of individual strains grown separately in pure cultures. Consistence of biocontrol efficacy and broad pest coverage, both major factors influencing the economics of a successful product, were addressed in this research. Treatments applied in both laboratory wounded potato bioassays and small pilot trials simulating commercial storage conditions were tested, as well as treatments challenged with dry rot, late blight, pink rot, and sprouting. Experiments were designed to analyze dry rot suppression versus all strain 
combinations and the combination method (co-culture or blend). Results of a two-way analysis of variance of disease with strain composition and combination method showed that significantly better dry rot suppression was obtained by co-cultures $(30.3 \pm 2.4 \%$ relative disease) than by similar strain blends of pure cultures $(41.3 \pm 2.4 \%)(\mathrm{P}<0.001)$. During a 3-year study, both biocontrol efficacy and consistency were assessed in 16 laboratory and small pilot trials simulating commercial storages. The 3-strain co-culture of Pseudomonas fluorescens strains S11:P:12, P22:Y:05, and S22:T:04 had a lower mean disease rating than the blend in 9 of 16 experiments examining control of the 3 diseases and sprouting. The co-culture led other treatments in incidences of significant malady reduction relative to the control: 14 of 16 attempts for co-culture, 11 of 16 attempts for blend, 10 of 13 attempts for pure S11:P:12, 8 of 13 attempts for S22:T:04, and 9 of 13 attempts for P22:Y:05. Using relative performance indices to rank treatment performance across all experiments, the co-culture treatment ranked significantly higher (69th percentile) than the blend (57th percentile). A synergy analysis suggested that co-culturing strains stimulated inter-strain activities to boost biocontrol efficacy and consistency, a feature not developed in strains grown separately and mixed just prior to addition to potatoes. Although the E. cloacae most often dominated co-cultures which included it, the other co-inoculated P. fluorescens populations persisted at significantly lower levels and apparently synergized the performance of the final population in suppressing dry rot disease.

There are a number of avenues by which the unique environment fostered by co-cultivation may improve biocontrol performance, and it is possible that inter-strain communication mechanisms are involved. Gram negative bacteria partners have been reported to regulate anti-microbial metabolite production via a signaling system referred to as "quorum sensing." Quorum sensing (QS) is mediated by population size and the accumulation of acylated homoserine lactones (AHL) which stimulate the bacterial populations to express genes responsible for metabolite production (Wood \& Pierson, 1996). The local fermentation environment of the co-culture may synergize the impact of such signaling on subsequent biological control performance. Arrays of AHLs are known to be produced by many common rhizosphere bacteria, and they allow not only signaling between cells within a strain population, but also between cells of different strain populations (Pierson et al., 1998). An AHL-mediated QS system was noted to regulate cell surface properties, which was different from that noted for anti-microbial phenazine production (Zhang \& Pierson, 2001). Soil bacteria have also been shown to degrade AHLs, such as via lactonase activity (Molina et al., 2003), a feature suggesting the potential for curative biocontrol of bacterial diseases. In addition to metabolite regulation and disease suppression, QS has been implicated in many other aspects of biocontrol activity, including: regulation of biofilm formation and rhizosphere colonization (Wei \& Zhang, 2006); pathogen virulence, motility, and fitness (Licciardello et al., 2007); indoleacetic acid (IAA) plant growth hormone synthesis (Müller et al., 2009), perhaps pertinent to IAA accumulation by our E. cloacae strain S11:T:07; and induced systemic resistance (Pang et al., 2009).

In addition to producing antifungal and sprout regulatory metabolites, we have recently identified the extracellular polysaccharide marginalan production by P. fluorescens S11:P:12 that not only improves its own survival during desiccation, but also that of co-inhabitants P22:Y:05 and S22:T:04 (Slininger et al., 2010a). This feature suggests the community benefit of one strain for others grown in association with it. In previous research by others, exopolysaccharides (EPS) have been associated with improved desiccation tolerance in 
Pseudomonas sp. (Roberson \& Firestone, 1992) and have been implicated as triggers to induced systemic resistance in host plants. It is believed that the EPS matrix slows the rate of water loss within the microenvironment, which enables the microbe additional time to make the necessary metabolic adjustments needed for survival. Relating to the current research, the co-culture of exopolysaccharide-producing Paenibacillus sp. with a Pseudomonas species has been reported to extend the shelf-life of the Pseudomonas for potential biopesticide or biofertilizer use (Kozyrovska et al., 2005). Thus, in addition to enhancing its biocontrol capacity, one of the benefits of our co-culture is that it includes an EPS-productive partner in P. fluorescens strain S11:P:12 that may protect bacteria against desiccation stress as they dry after application to tuber surfaces. The discovery of other mechanisms benefiting the function of the co-culture for consistent and efficacious biological control will likely be among the objectives of future research. Meanwhile, the advantages of co-culturing are compelling and spur on development efforts: economical production of multiple strains in one culture, broad disease spectrum, beneficial interactions of strains, desiccation sheltering, enhanced efficacy, and enhanced consistence.

\section{Production considerations}

For each strain of interest, the liquid culture production and biocontrol agent formulation processes must be designed to minimize cost and maximize production rate, yield, and quality, i.e. bioefficacy, storage stability, and host compatibility. The impact of liquid culture conditions (carbon and nitrogen sources, carbon-to-nitrogen ratio, nutrients, temperature, $\mathrm{pH}$, dissolved oxygen), microbial physiology (growth state) and metabolites on the qualities of the biocontrol product will all need to be considered when designing the production processes for successful biocontrol products. To illustrate this, key findings of our research on this subject will be reviewed for a variety of our biological control agents under development, including but not exclusively our agents for post-harvest potatoes.

\subsection{Manipulation of growth, metabolism, and efficacy with culture conditions}

Prior research has shown that culture environment impacts metabolite accumulations and biocontrol agent quality. When strain Pseudomonas fluorescens 2-79 (NRRL B-15132) is efficiently delivered to the field in seed coatings, it colonizes the emerging root and produces the antibiotic, phenazine-1-carboxylic acid (PCA), as its primary means of suppressing take-all disease [incited by Gaemannomyces graminis var. tritici (Ggt)]. Our research has shown that metabolites (primarily PCA) present in liquid cultures of strain 2-79 cause significant germination losses (up to $64 \%$ ) when included in seed coatings. In mass production of seed inocula, complete separation of cells from metabolites adds considerable expense and may not be feasible if metabolites are insoluble. For Pseudomonas fluorescens 279 , the phytotoxicity of the cell harvest can jeopardize the most economical method of application of the biocontrol agent, which is as a wheat seed coating. Our research showed that controlling fermentor environment allowed dramatic reduction of phytotoxic metabolite production. Fermentation conditions, such as dissolved oxygen, carbon source, $\mathrm{pH}$, or temperature, were controlled to allow production of cells in a phytotoxin-free culture broth which could be used directly to treat seeds without sacrifice to either seed germination or to take-all disease control via PCA production in the rhizosphere (Slininger \& SheaWilbur, 1995; Slininger et al., 1997a, 1998). 
Culture environment also impacts the metabolism and efficacy of our potato protective rhizobacteria which have been reported to produce at least one antifungal component per strain (Burkhead et al., 1995). Our process for ranking dry rot antagonists relative to commercial potential involved growing the strains on three different liquid media of varying nutritional richness and then applying them to potato wounds challenged by the pathogen. The rank of candidate strains based on the liquid culture growth and also disease suppressiveness of the product was found to vary widely with the nutritional environment provided during production of the biological control agent. The metabolite profile of E. cloacae strain S11:T:07 has been studied in detail, and it is known to produce indoleacetic acid, phenyl acetic acid, and tyrosol. Concentrations of these metabolites influence both disease suppression and sprouting and vary in cultures with the nutritional environment (Burkhead et al., 1998; Slininger et al., 2004). As discussed in section 7 above, the cocultivation of multiple potato malady-suppressive strains gives rise to a unique fermentation environment that can yield a biocontrol product with improved efficacy and consistency (Slininger et al., 2010b). However, additional process optimization challenges may arise in accommodating population yields, storage stability, and efficacy. Although the performance benefits of co-cultivations to biocontrol performance had not been documented prior to our 2010 report, mixed Pseudomonad cultivations (with other Pseudomonas sp. or other genera) have been documented for many other applications (for example, Rodriguez \& Gallardo, 1993; Kimura \& Ito, 2001; Ashby et al., 2005; Kumar et al., 2006). More recently, Wu et al. (2009) examined the synergistic growth of a salt tolerant Pseudomonas fluorescens Rs-198 with another bacterium Rs-5 in co-culture that may have potential for application in fertilizer preparation. Co-cultures of potato-protective P. fluorescens strains could easily be designed to develop similar population densities even by simple adjustments in initial population densities to compensate for growth differences in strains as evaluated by a non-antibiotic selective plating technique described in Slininger et al. (2010b) (Figure 3).

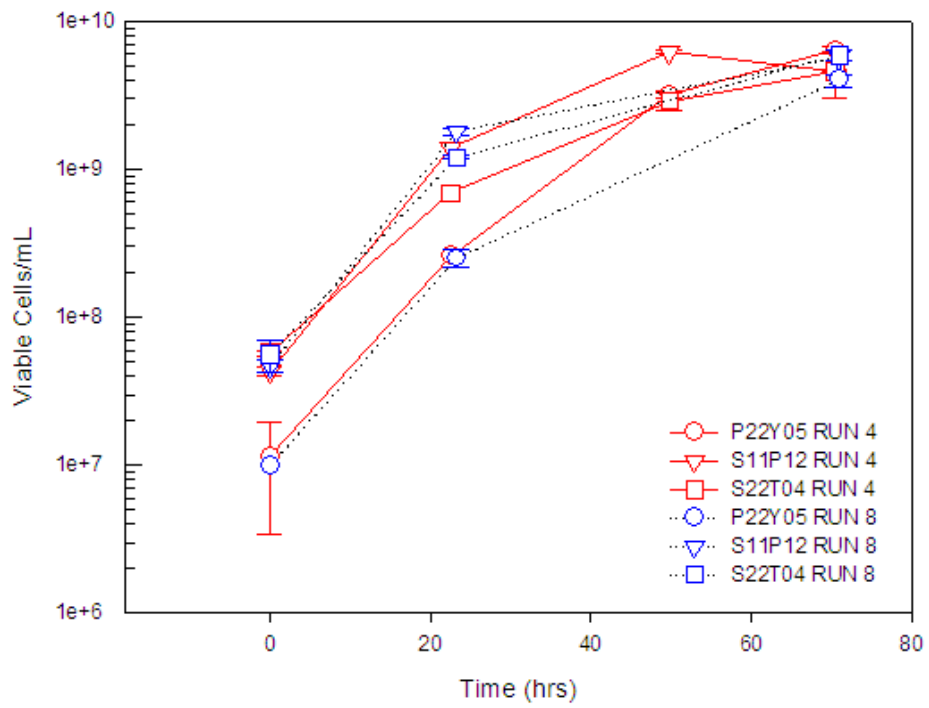

Fig. 3. Growth of P. fluorescens strains S11:P:12, P22:Y:05, and S22:T:04 in duplicate coculture fermentor runs (Slininger et al., 2010b). 
Though still synergistic to efficacy, $P$. fluorescens populations persisted at significantly lower levels than co-cultured E. cloacae S11:T:07 a facultative anaerobe with significant competitive advantage as dissolved oxygen is depleted. Growth suppression of multi-species bacterial populations in batch cultures by a single dominant strain has been referred to in the literature as the Jameson Effect and often involves production of specific inhibitors by one species against another. Future work may reveal inoculum population management and nutritional or physical environment management techniques that would allow testing the biocontrol efficacy of controllable population distributions of multi-genera co-cultures like $P$. fluorescens and E. cloacae strains, allowing investigation into the optimization of relative strain densities.

\subsection{Influence of culture and physiological conditions on dry storage survival}

The physiological state of cells upon harvest from the fermentation process was another factor that has been observed to influence the drying survival and shelf-life of strain 2-79 cells coated in $0.5 \%$ methylcellulose onto wheat seeds. Cells harvested from growth phase cultures $(24-48 \mathrm{~h})$ survived the drying process better than cells from stationary phase cultures (72-96 h), but stationary phase cells had a longer shelf-life than did growth phase cells. Our data suggest that the protective effect of residual sugar still present in growing cultures may explain why growth phase cells exhibited better survival of the drying process than did stationary cells that were deplete of sugar. The longer shelf-life of the stationary phase cells may come about via one or more of a variety of mechanisms that occur as a result of cell starvation and aging as reviewed by Slininger et al. (1996b, 1998). This feature has also been observed in our potato protective rhizobacteria and that influenced our choice of a 72-h harvest for our co-cultures in current research (Slininger et al., 2010a). The impact of cultivation conditions on biocontrol agent storage stability have been shown in virtually every other biocontrol system studied in our laboratory and not just those involving the control of plant diseases with rhizobacteria. Varying the carbon to nitrogen ratio and total carbon loading of a liquid medium for producing the bioherbicide Colletotrichum truncatum altered its dry storage stability as well as quantity, propagule type (conidia versus microsclerotia), and efficacy (Schisler et al., 1991; Jackson \& Schisler, 1995). Yield and desiccation-tolerance of blastospores of the mycoinsecticide Paecilomyces fumosoroseus required appropriate concentrations of amino acids (Jackson, 1997; Jackson et al., 1997). Carbon-to-nitrogen ratio and carbon loading were found to influence the freeze-drying survival and Fusarium head blight suppressiveness of Cryptococcus nodaensis (now $C$. flavescens) OH 182.9 (Zhang et al., 2005); and cold shock during liquid cultivation increased the storage shelf-life of this biocontrol agent after air drying (Zhang et al., 2006).

\subsection{Formulating for storage stability and delivery}

Once the microbial biological control agent is harvested from the production culture, it will be necessary to formulate it. Formulations can be designed to meet a variety of objectives: to prevent biocontrol agent activity losses during storage; to facilitate convenient and efficacious delivery of the agent to the area where biocontrol is needed in the field; to promote insect biocontrol agent or plant-biocontrol agent compatibility; and to enhance the effectiveness of the biocontrol agent delivered. Examples are reviewed to illustrate formulation techniques devised by our research group to accomplish each of these goals for specific biocontrol problems. 
The loss of microbial viability during storage is one of the most challenging barriers to overcome on the road to commercial success, especially for strains that do not form a resilient spore. Formulation matrices and storage temperature can play an important role in improving storage survival. For example, in the case of Paecilomyces fumosoroseus blastospores, calcined kaolin clay allowed significantly better drying survival and storage stability than other matrices tested (diatomaceous earth, talcs, corn starch, rice flour, and Mexican lime). Greater than $70 \%$ survival was retained after air drying and storage 42 days at $4^{\circ} \mathrm{C}$, and near $20 \%$ after 21 days at $28^{\circ} \mathrm{C}$ was retained using $5 \%$ clay (SandovalCoronado et al., 2001). The trend of longer term storage survival with decreasing storage temperature has also held true for liquid formulations of Pseudomonas fluorescens and Enterobacter cloacae, our gram-negative bacterial biocontrol agents of potato dry rot and sprouting; cells frozen at $-20^{\circ} \mathrm{C}$ in neutral buffer exhibited half-lives of 72-161 days, while those refrigerated at $4^{\circ} \mathrm{C}$ had half-lives of only 12-33 days (Slininger et al., 1997b). Another general finding of our work has been that the inclusion of culture broth with cells in stored formulations is often, but not always, detrimental to long term cell survival. For example, our gram-negative biocontrol agents for potatoes exhibited half-lives of 26-97 days when frozen in their culture broth and half-lives of 12-42 days when refrigerated in their culture broth. Thus, when frozen, the cells formulated in culture broth had poorer survival than cells in buffer, but when refrigerated, cell survival was similar in culture broth and buffer. When Pseudomonas fluorescens 2-79 was stored refrigerated in dried methylcellulose coatings of wheat seeds, the presence of the culture broth was again observed to be detrimental to drying and long-term cell survival, but the data showed that the presence of glucose in methylcellulose coatings with culture broth reduced cell losses upon drying (Slininger et al., 1996b). These examples illustrate the impact of formulation and storage conditions on biocontrol agent preservation and suggest both the aptitude and need for technology advancement in this area.

\subsection{Exopolysaccharide production and use as an in situ formulant}

Suppressive to potato diseases and sprouting, Pseudomonas fluorescens S11:P:12 (NRRL B21133) produces a polysaccharide during liquid cultivation which was isolated, purified, and identified as marginalan (Slininger et al., 2010a). Dry storage results indicated that the presence of marginalan significantly reduced cell death after drying, such that the final stable viable cell density was 2.5 to 5 orders of magnitude greater, respectively, than if no marginalan were included with cells. Marginalan had no significant impact on disease or sprout suppression by strain S11:P:12, and its main benefit to biocontrol was viable cell preservation during drying and storage. When marginalan was formulated with other selected P. fluorescens strains P22:Y:05 and S22:T:04, as may occur in co-cultures, its benefits to drying and storage survival were again evident, though more subtle than observed for strain S11:P:12 - perhaps because it was the most sensitive of the three to drying. Due to marginalan production, higher viscosity and higher fermentation power consumption for aeration and mixing will be needed to maximize viable cell yield in cultures containing S11:P:12. On the other hand, the polysaccharide offers to return value in terms of enhanced biological control as a cell desiccation protectant and should be considered in culture optimization schemes and for use in downstream formulation methodologies. 


\begin{tabular}{cccc}
\hline $\begin{array}{c}\text { Storage } \\
\begin{array}{c}\text { Relative Humidity } \\
(\%)\end{array}\end{array}$ & $\begin{array}{c}\text { Time to } \\
\text { A620=0.05 } \\
(\mathrm{h})^{\mathrm{a}}\end{array}$ & $\begin{array}{c}\text { Surviving } \\
\text { Viable Cells } \\
(\mathrm{cfu} / \mathrm{well})^{\mathrm{a}}\end{array}$ & $\begin{array}{c}\text { Relative Dry Rot } \\
\text { Disease Rating } \\
(\%)^{\mathrm{a}}\end{array}$ \\
\hline 51 & $5.6 \mathrm{~A}$ & $4.4 \times 10^{8} \mathrm{~A}$ & $58.6 \mathrm{~A}$ \\
86 & $8.7 \mathrm{~B}$ & $4.3 \times 10^{8} \mathrm{~A}$ & $49.7 \mathrm{~A}$
\end{tabular}

\begin{tabular}{|c|c|c|c|}
\hline $\begin{array}{l}\text { Formulation } \\
\text { Sugar }\end{array}$ & & & \\
\hline Lactose + BSA & $5.8 \mathrm{~A}$ & $3.9 \times 10^{6} \mathrm{~A}$ & $56.4 \mathrm{~A}$ \\
\hline Lactose & $7.0 \mathrm{AB}$ & $5.8 \times 10^{6} \mathrm{~A}$ & $66.9 \mathrm{~A}$ \\
\hline Sucrose & $7.2 \mathrm{AB}$ & $3.4 \times 10^{6} \mathrm{~A}$ & $57.4 \mathrm{~A}$ \\
\hline Fructose & $8.6 \mathrm{~B}$ & $4.4 \times 10^{6} \mathrm{~A}$ & 35.9 \\
\hline
\end{tabular}

Storage Time

\begin{tabular}{cccc}
$(\mathrm{d})$ & & & \\
77 & $3.8 \mathrm{~A}$ & $1.1 \times 10^{7} \mathrm{~A}$ & $52.0 \mathrm{~A}$ \\
48 & $4.4 \mathrm{AB}$ & $3.5 \times 10^{6} \mathrm{~B}$ & $47.2 \mathrm{~A}$ \\
83 & $7.1 \mathrm{~B}$ & $2.4 \times 10^{6} \mathrm{~B}$ & $55.5 \mathrm{~A}$ \\
145 & $13.4 \mathrm{C}$ & $1.3 \times 10^{6} \mathrm{~B}$ & $62.3 \mathrm{~A}$ \\
\hline
\end{tabular}

aWithin each column and storage factor, means having letters in common are not significantly different $(\mathrm{P}<0.05)$.

Table 2. Impact of storage conditions on drying survival of Enterobacter cloacae S11:T:07 in the droplet drying screena (Slininger and Schisler, 2003)

\section{Filling the gaps to commercialization - A high-throughput screening concept for optimizing biocontrol performance}

In conclusion, much progress has been made with methods of screening and selecting commercially useful biological control agents and in identifying key aspects of cultivation and formulation that impact biocontrol agent yield and quality. However, the development and optimization of integrated technologies to produce and deliver effective biological control agents remains a barrier to commercialization for many biocontrol agents. We have noted a myriad of variables associated with biocontrol agent cultivation, formulation, drying, storage, and reconstitution processes complicate agent quantity and quality maximization. To approach this problem, an efficient assay was conceived and applied using a 96-well microplate format to allow an integrated approach to optimizing these process variables. The basic high-throughput screening assay is depicted in Figure 4 and involves growing the BCA of interest (in flasks, fermentors, or microplates), formulating cells harvested from growth cultures, delivering microliter droplets of formulated cells to microplate wells (for rapid or slow drying), air- or freeze-drying droplets in the wells, storing plates, reconstituting dried cells, and then monitoring cell activity in terms of the rate of cell growth to a specified yield using a plate-reading spectrophotometer (Slininger \& Schisler, 2003). Relevant variables (ingredients, temperature, etc.) are treated at each step of the assay process to view their individual and combined impact on resultant microbial activity, 
such as the speed of reaching logarithmic growth and a certain cell yield, such as in this research an optical density of 0.05 at a defined wavelength $(620 \mathrm{~nm})$. A kinetic activity assessment such as this is convenient to accomplish for the numerous samples that can potentially arise in multivariate experiments and is a good initial screen of biocontrol agent activity as it relates to viable cell concentration in combination with cell activity level (Figure 4).
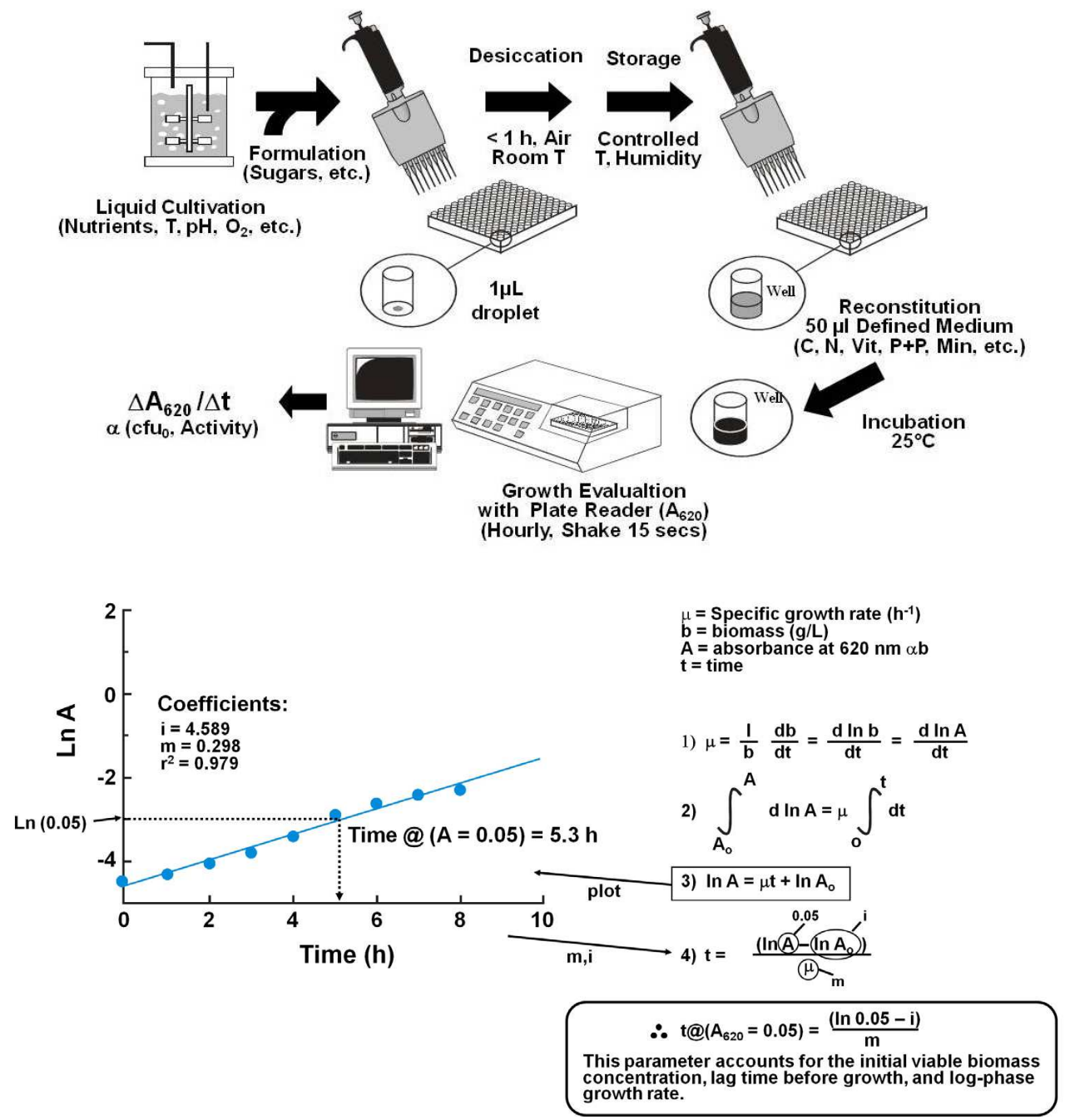

Fig. 4. Droplet drying method to screen and optimize integrated biocontrol agent production process variables (Slininger and Schisler, 2003)

Numerous variables (culture and formulation ingredients, temperature, humidity, etc.) can be tested at each step of the assay process to view their individual and combined impact on the resultant microbial activity. The results of such an assay applied to our potato dry rot 
protective strain S11:T:07 are shown in Table 2 along with the results of other quality assays that can be carried out on microsamples, including viable cell counts and a wounded potato disease suppressiveness assay. We are currently applying such a flexible approach to allow further optimization of an integrated production process that would support biocontrol agent commercialization in the near future.

\section{Disclaimer}

The mention of trade names or commercial products in this article is solely for the purpose of providing specific information and does not imply recommendation or endorsement by the U.S. Department of Agriculture. USDA is an equal opportunity provider and employer.

\section{References}

Abu-El Samen, F.M., Oberoi, K., Taylor, R.J., Secor, G.A. \& Gudmestad, N.C. (2005). Inheritance of mefenoxam resistance in selfed populations of the homothallic oomycete Phytophthora erythroseptica (Pethybr.), cause of pink rot of potato. American Journal of Potato Research 82: 105-115

Adiyaman, T., Schisler, D.A., Slininger, P.J., Sloan, J.M., Jackson, M.A. \& Rooney, A.P. (2011). Selection of biocontrol agents of pink rot based on efficacy and growth kinetics index rankings. Plant Disease 95(1): 24-30

ASAE (1990). Design and management of storages for bulk, fall-crop Irish potatoes. St. Joseph, MI: ASAE

Ashby, R.D., Solaiman, D.K.Y. \& Foglia, T.A. (2005). Synthesis of short/medium-chainlength poly(hydroxyalkanoate) blends by mixed culture fermentation of glycerol. Biomacromolecules 6: 2106-2112

Baker, K.F. (1987). Evolving concepts of biological control of plant pathogens. Annual Reviews of Phytopathology 25: 67-85

Behle, R.W., Tamez-Guerra, P., Shasha, B.S. \& McGuire, M.R. (1999). Formulating bioinsecticides to improve residual activity. Proceedings of the Formulations Forum, March 3-5, Orlando, FL

Boyd, A.E.W. (1972). Potato storage diseases. Reviews of Plant Pathology 51: 297-321

Burkhead, K.D., Schisler, D.A. \& Slininger, P.J. (1995). Bioautography shows antibiotic production by soil bacterial isolates antagonistic to fungal dry rot of potatoes. Soil Biology and Biochemistry 27(12): 1611-1616

Burkhead, K.D., Slininger, P.J. \& Schisler, D.A. (1998). Biological control bacterium Enterobacter cloacae S11:T:07 (NRRL B-21050) produces the antifungal compound phenylacetic acid in Sabouraud maltose broth culture. Soil Biology and Biochemistry 30(5): 665-667

Cruz, L.P., Gaitan, A.L. \& Gongora, C.E. (2006). Exploiting the genetic diversity of Beauveria bassiana for improving the biological control of the coffee berry borer through the use of strain mixtures. Applied Microbiology and Biotechnology 71: 916-926

Desjardins, A.E., Christ-Harned, E.A., McCormick, S.P. \& Secor, G.A. ( 1993). Population structure and genetic analysis of field resistance to thiabendazole in Gibberella pulicaris from potato tubers. Phytopathology 83: 164-170 
Desjardins, A.E. \& Plattner, R.D. (1989). Trichothecene toxin production by strains of Gibberella pulicaris (Fusarium sambucinum) in liquid culture and in potato tubers. Journal of Agricultural and Food Chemistry 37: 388-392

Duffy, B.K., Simon, A. \& Weller, D.M. (1996). Combination of Trichoderm koningii with fluorescent Pseudomonads for control of take-all on wheat. Phytopathology 86: 188194

Duffy, B.K. \& Weller, D.M. (1995). Use of Gaeumannomyces graminis var. graminis alone and in combination with fluorescent Pseudomonas spp. to suppress take-all of wheat. Plant Disease 79: 907-911

EPA (1996). EPA 738-R-96-023 Registration Eligibility Decision. Environmental Protection Agency

Fairclough, R.W., Bain, R.A. \& Holmes, S.J. (1997). The infection of potatoes by Phytophthora infestans during simulated washing and its control using a hot water treatment. Potato Research. 40: 91-99

Fravel, D.R. (1988). Role of antibiosis in the biocontrol of plant diseases. Ann. Rev. Phytopathology 26: 75-91

Fry, W.E., Thurston, H.D., \& Stevenson, W.R. (2001). Late blight, In: Compendium of Potato Diseases, W.R. Stevenson, R. Loria, G.D. Franc \& D.P. Weingartner (Eds.), 28-30, APS Press, St. Paul, MN

Geutsky, R., Shtienberg, D., Elad, Y. \& Dinoor, A. (2001). Combining biocontrol agents to reduce the variability of biological control. Phytopathology 91: 621-627

Hanson, L.E., Schwager, S.J. \& Loria, R. (1996). Sensitivity to thiabendazole in Fusarium species associated with dry rot of potato. Phytopathology 86: 378-384

Homma, Y. \& Suzui, T. (1989). Role of antibiotic production in suppression of radish damping off by seed bacterization with Pseudomonas cepacia. Annals of the Phytopathological Society of Japan 55: 643-652

Huang, H.C. (1991). Control of soilborne pathogens by mycoparasites: prospects and constraints. In The Biological Control of Plant Diseases, J. Bay-Petersen (Ed.), 130-141, Kuo Thai Color Printing Co., Ltd., Japan

Hwang, J. \& Benson, D.M. (2002). Biocontrol of rhizoctonia stem and root rot of poinsettia with Burkholderia cepacia and binucleate Rhizoctonia. Plant Disease 86: 47-53

Jackson, M.A. (1997). Optimizing nutritional conditions for the liquid culture prduction of effective fungal biological control agents. Journal of Industrial Microbiology and Biotechnology 19: 180-187

Jackson, M.A., McGuire, M.R., Lacey, L.A. \& Wraight, S.P. (1997). Liquid culture production of desiccation tolerant blastospores of the bioinsecticidal fungus Paecilomyces fumosoroseus. Mycological Research 101: 35-41

Jackson, M.A. \& Schisler, D.A. (1995). Liquid culture production of microsclerotia of Colletotrichum truncatum for use as bioherbicidal propagules. Mycological Research 99: 879-884

Janisiewicz, W.J. (1988). Biocontrol of postharvest diseases of apples with antagonist mixtures. Phytopathology 78: 194-198 
Janisiewicz, W.J. (1991). Biological control of post harvest fruit diseases. In: Handbook of Applied Mycology, Volume 1: Soil and Plants, D.K. Arora, B. Rai, K.G. Mukerji \& G.R. Knudsen, (Eds.), 301-326, Marcel Dekker, Inc., New York

Janisiewicz, W.J. (1996). Ecological diversity, niche overlap, and coexistence of antagonists used in developing mixtures for biocontrol of post-harvest diseases of apples. Phytopathology 86: 473-479

Janisiewicz, W.J. \& Korsten, L. (2002). Biological control of postharvest diseases of fruits. Annual Review of Phytopathology 40: 411-441

Johnson, D.A., Inglis, D.A. \& Miller, J.S. (2004). Control of potato tuber rots caused by oomycetes with foliar applications of phosphorous acid. Plant Disease 88: 1153-1159

Kawchuk, L.M., Holley, J.D., Lynch, D.R. \& Clear, R.M. (1994). Resistance to thiabendazole and thiophanate-methyl in Canadian isolates of Fusarium sambucinum and Helminthosporium solani. American Potato Journal 71: 185-192

Kimura, T. \& Ito, Y. (2001). Two bacterial mixed culture systems suitable for degrading terephthalate in wastewater. Journal of Bioscience and Bioengineering 91: 416-418

Kozyrovska, N.O., Negrutska, V.V., Kovalchuk, M.V. \& Voznyuk, T.N. (2005). Paenibacillus sp., as a promising candidate for development of a novel technology of inoculants production. Biopolimeri Klitina 21:312-318

Krauss, U. \& Soberanis, W. (2001). Biocontrol of cocoa pod diseases with mycoparasite mixtures. Biological Control 22: 149-158

Kumar, M., Leon, V., DeSisto Materano, A. \& Ilzins, O.A. (2006). Enhancement of oil degradation by co-culture of hydrocarbon degrading and biosurfactant producing bacteria. Polish Journal of Microbiology 55: 139-146

Lambert, D.H., Currier, A.I. \& Olanya, M.O. (1998). Transmission of Phytophthora infestans in cut potato seed. American Journal of Potato Research. 75: 257-263

Lazarovits, G., Brammall, R.A. \& Ward, E.W.B. (1982). Bioassay of fungitoxic compounds on thin-layer chromatograms with Pythium and Phytophthora species. Phytopathology 72: 61-63

Leeman, M., Den Ouden, F.M., Van Pelt, J.A., Cornelissen, C., Matamala-Garros, A., Bakker, P.A.H.M. \& Schippers, B. (1996). Suppression of Fusarium wilt of radish by coinoculation of fluorescent Pseudomonas spp. and root-colonizing fungi. Journal of Plant Pathology 102: 21-31

Lewis, M.D., Thornton, M.K. \& Kleinkopf, G.E. (1996). Understand why CIPC is a necessity. Potato Grower 25(9) : 8-9

Licciardello, G., Bertani, I., Steindler, L., Bella, P., Venturi, V. \& Catara, V. (2007). Homoserine lactone quorum sensing system: its role in tomoto pathogenicity and tobacco hypersensitivity response. FEMS Microbiology Ecology 61: 222-234

Loper, J.E. \& Buyer, J.S. (1991). Siderophores in microbial interactions on plant surfaces. Molecular Plant-Microbe Interactions 4: 5-13

Martiniez Noel, G.M.A., Madrid, E.A., Bottini, R. \& Lamattina, L. (2001). Indole acetic acid attenuates disease severity in potato-Phytopthora infestans interaction and inhibits the pathogen growth in vitro. Plant Physiology and Biochemistry. 39: 815-823 
Medugno, C.C., Ferraz, J.M.G., Maia, A.H.N. \& Freitas, D. L. (1997). Evaluation of a wettable powder formulation for the nuclear polyhedrosis virus of Anticarsia gemmatalis (Lep.:Noctuidae). Pesticide Science 51: 153-156

Miller, J.S., Olsen, N., Woodell, L., Porter, L.D. \& Clayson, S. (2006). Post-harvest applications of zoxamide and phophite for control of potato tuber rots caused by oomycetes at harvest. American Journal of Potato Research. 83: 269-278

Mills, A.A.S., Platt, H.W.B. \& Hurta, R.A.R. (2005). Salt compounds as control agents of late blight and pink rot of potatoes in storage. Canadian Journal of Plant Pathology. 27: 204-209

Molina, L., Constantinescu, F., Michel, L., Reimmann, C., Duffy, B. \& Defago, G. (2003). Degradation of pathogen quorum-sensing molecules by soil bacteria: a preventative and curative biological control mechanism. FEMS Microbiology Ecology 45: 71-81

Mondy, N.I., Sharada, D., Munshi, C.B. \& Wurm, C.M. (1992). Effect of storage time, temperature, and cooking on isopropyl N-(3-chlorophenyl) carbamate levels in potatoes. Journal of Agricultural and Food Chemistry 40: 197-199

Müller, H., Westendorf, C., Leitner, E., Chernin, L., Riedel, K., Schmidt, S., Eberl, L. \& Berg, G. (2009). Quorum-sensing effects in the antogonistic rhizosphere bacterium Serratia plymuthica HRO-C48. FEMS Microbiology Ecology 67: 468-478

Pang, Y., Liu, X., Ma, Y., Chernin, L., Berg, G. \& Gao, K. (2009). Induction of systemic resistance, root colonization and biocontrol activities of the rhizospheric strain of Serratia plymuthica are dependent on N-acyl homoserine lactones. Plant Pathology 124: 261-268

Pawlak, A., Pavek, J.J., \& Corsini, D.L. (1987). Resistance to storage diseases in breeding stocks. In: The Production of New Potato Varieties: Technological Advances, G.J. Jellis \& D.E. Richardson, (Eds.), 96-98, Cambridge University Press, New York

Peters, R.D., Clark, R.J., Coffin, A.D., Sturz, A.V., Lambert, D.H. \& Miller, J.S. (2005). Limited genetic diversity in North American isolates of Phytophthora erythroseptica pathogenic to potato based on RAPD analysis. Plant Disease 89: 380-384

Peters, R.D., Sturz, A.V. \& Arsenault, W.J. (2004). Tuber response of six potato cultivars to inoculation with Phytophthora erythroseptica, the causal agent of pink rot. Canadian Journal of Plant Pathology 26: 63-69

Pierson, E.A. \& Weller, D.M. (1994). Use of mixtures of fluorescent Pseudomonads to suppress take-all and improve the growth of wheat. Phytopathology 84: 940-947

Pierson, E.A., Wood, D.W., Cannon, J.A., Blachere, F.M. \& Pierson III, L.S. (1998). Interpopulation signaling via $\mathrm{N}$-acyl-homoserine lactones among bacteria in the wheat rhizosphere. Molecular Plant-Microbe Interactions 11: 1078-1084

Reiners, S. \& Petzoldt, C.H. (2004). Chapter 24 Potatoes. In: Cornell Integrated Crop and Pest Management Guidelines for Vegetable Crops, S. Reiners \& C.H. Petzoldt, (Eds.). http://www.nysaes.cornell.edu/recommends

Reisch, M.S. (2011). Going mainstream biopesticide producers look beyond organic growers. Chemical and Engineering News 89(16): 16 
Roberson, E.B. \& Firestone, M.K. (1992). Relationship between desiccation and exopolysaccharide production in a soil Pseudomonas sp. Applied and Environmental Microbiology 58: 1284-1291

Rodriguez, H. \& Gallardo, R. (1993). Single-cell protein production from bagasse pith by a mixed bacterial culture. Acta Biotechnologica 13: 141-149

Sandoval-Coronado, C.F., Luna-Olvera, H.A., Arevalo-Nino, K., Jackson, M.A., Poprawski, T.J. \& Galan-Wong, L.J. (2001). Drying and formulation of blastospores of Paecilomyces fumosoroseus (Hyphomycetes) produced in two different liquid media. World Journal of Microbiology and Biotechnology 17: 423-428

Schisler, D.A. (1997). The impact of phylloplane microorganisms on mycoherbicide efficacy and development. In: The Mycota: Vol 5, Environmental and Microbial Relationships, 219-235, B. Soderstrom \& D.T. Wicklow, (Eds.), Springer-Verlag, New York

Schisler, D.A., Boehm, M.J. \& Slininger, P.J. (2005). Dosage requirements and combinations of choline metabolizing strains and antagonist Cryptococcus nodaensis $\mathrm{OH} 182.9$ for reducing FHB of wheat. Phytopathology 95: $S 93$

Schisler, D.A., Bothast, R.J. \& Slininger, P.J. (1998a).Bacterial Control of Fusarium Dry Rot of Potatoes. United States Patent No. 5783411

Schisler, D.A., Jackson, M.A. \& Bothast, R.J. (1991). Influence of nutrition during conidiation of Colletotrichum truncatum on conidial germination and efficacy in inciting disease in Sesbania exaltata. Phytopathology 81: 587-590

Schisler, D.A. \& Slininger, P.J. (1994). Selection and performance of bacterial strains for biologically controlling Fusarium dry rot of potatoes incited by Gibberella pulicaris. Plant Disease 78: 251-255

Schisler, D.A., Slininger, P.J. \& Bothast, R.J. (1997). Effects of antagonist cell concentration and two-strain mixtures on biological control of Fusarium dry rot of potatoes. Phytopathology 87(2): 177-183

Schisler, D.A., Slininger, P.J., Hanson, L.E. \& Loria, R. (2000a). Potato cultivar, pathogen isolate and antagonist cultivation medium influence the efficacy and ranking of bacterial antagonists of Fusarium dry rot. Biocontrol Science and Technology 10: 267279

Schisler, D.A., Slininger, P.J., Kleinkopf, G., Bothast, R.J. \& Ostrowski, R.C. (2000b). Biological control of Fusarium dry rot of potato tubers under commercial storage conditions. American Journal of Potato Research 77: 29-40

Schisler, D.A., Slininger, P.J., Miller, J.S., Woodell, L.K., Clayson, S. \& Olsen, N. (2009). Bacterial antagonists, zoospore inoculum retention time and potato cultivar influence pink rot disease development. American Journal of Potato Research 86: 102111

Secor, G.A. \& Gudmestad, N.C. (1999). Managing fungal diseases of potato. Canadian Journal of Plant Pathology 21: 213-223

Secor, G.A., Rodriguez, D., Rodriguez, J. \& Gudmestad, N.C. (1994). Distribution and incidence of benzimidazole-resistant Fusarium sambucinum and Helminthosporium solani isolated from potato in North America. Fungicide Resistance BCPC Monogr. No. 60: 271-274 
Secor, G.A. \& Salas, B. (2001). Fusarium dry rot and Fusarium wilt, In: Compendium of Potato Diseases, W.R. Stevenson, R. Loria, G.D. France \& D.P. Weingartner, (Eds.), 23-25, APS Press, St. Paul, MN

Slininger, P.J. \& Schisler, D.A. (2003). High throughput assay for optimizing microbial biological control agent production and delivery. Phytopathology 93: S79

Slininger, P.J., Burkhead, K.D. \& Schisler, D.A. (2004). Antifungal and sprout regulatory bioactivities of phenylacetic acid, indole-3-acetic acid, and tyrosol isolated from the potato dry rot suppressive bacterium Enterobacter cloacae S11:T:07. Journal of Industrial Microbiology and Biotechnology 31: 517-524

Slininger, P.J., Burkhead, K.D., Schisler, D.A. \& Bothast, R.J. (2000). Biological control of sprouting of potatoes. United States Patent No. 6107247

Slininger, P.J., Dunlap, C.A. \& Schisler, D.A. (2010a). Polysaccharide production benefits dry storage survival of the biocontrol agent Pseudomonas fluorescens S11:P:12 effective against several maladies of stored potatoes. Biocontrol Science and Technology 20(3): 227-244

Slininger, P.J., Schisler, D.A. \& Bothast, R.J. (1994).Two-dimensional liquid culture focusing: A method of selecting commercially promising microbial isolates with demonstrated biological control capability, In: Improving Plant Productivity with Rhizosphere Bacteria, Proceedings of the Third International Workshop on Plant GrowthPromoting Rhizobacteria, M.H. Ryder, P.M. Stephens \& G.D. Bowen (Eds.), 29-32, Adelaide, South Australia: CSIRO

Slininger, P.J., Schisler, D.A. \& Bothast, R.J. (1996a). Bacteria for the control of Fusarium dry rot to potatoes. United States Patent No. 5552315.

Slininger, P.J., Schisler, D.A., Burkhead, K.D. \& Bothast, R.J. (2003). Postharvest biological control of potato sprouting by Fusarium dry rot suppressive bacteria. Biocontrol Science and Technology 13(5): 477-494

Slininger, P.J., Schisler, D.A., Burkhead, K.D., Ostrowski, R.C., \& Bothast, R.J. (1997b). Development of biological agents for the control of Fusarium dry rot disease of stored potatoes. American Potato Journal 74: 467-468

Slininger, P.J., Schisler, D.A., Ericsson, L.D., Brandt, T.L., Frazier, M.J., Woodell, L.K., Olsen, N.L. \& Kleinkopf, G.E. (2007). Biological control of post-harvest late blight of potatoes. Biocontrol Science and Technology 17(5/6): 647-663

Slininger, P.J., Schisler, D.A. \& Kleinkopf, G. 2001. Combinations of dry rot antagonistic bacteria enhance biological control consistency in stored potatoes. Phytopathology 91: S83

Slininger, P.J., Schisler, D.A., Shea-Andersh, M.A., Sloan, J.M., Woodell, L.K., Frazier, M.J. \& Olsen, N. (2010b). Multi-strain co-cultures surpass blends for broad spectrum biological control of maladies of potatoes in storage. Biocontrol Science and Technology 20(8): 763-786

Slininger, P.J. \& Shea-Wilbur, M.A. (1995). Liquid-culture $\mathrm{pH}$, temperature, and carbon (not nitrogen) source regulate phenazine productivity of the take-all biocontrol agent Pseudomonas fluorescens 2-79. Applied Microbiology and Biotechnology 43: 794-800

Slininger, P.J., VanCauwenberge, J.E., Bothast, R.J., Weller, D.M., Thomashow, L.S. \& Cook, R.J. (1996b). Effect of growth culture physiological state, metabolites, and 
formulation on the viability, phytotoxicity, and efficacy of the take-all biocontrol agent Pseudomonas fluorescens 2-79 stored encapsulated on wheat seeds. Applied Microbiology and Biotechnology 45: 391-398

Slininger, P.J., VanCauwenberge, J.E., Shea-Wilbur, M.A. \& Bothast, R.J. (1998). Impact of liquid culture physiology, environment, and metabolites on biocontrol agent qualities: Pseudomonas fluorescens 2-79 versus wheat take-all, In: Plant-Microbe Interactions and Biological Control, G.G. Boland \& L.D. Kuykendall (Eds.), 329-353, Marcel Dekker, Inc., New York, NY

Slininger, P.J., VanCauwenberge, M.A., Shea-Wilbur, M.A., Burkhead, K.D., Schisler, D.A. \& Bothast, R.J. (1997a). Reduction of phenazine-1-carboxylic acid accumulation in growth cultures of the biocontrol agent Pseudomonas fluorescens 2-79 eliminates phytotoxic effects of wheat seed inocula without sacrifice to take-all suppressiveness, In: Plant Growth-promoting Rhizobacteria: Present Status and Future Prospects, Proceedings of the Fourth International Workshop on Plant Growth-promoting Rhizobacteria Japan-OECD Joint Workshop, A. Ogoshi, K. Kobayashi, Y. Homma, F. Kodama, N. Kondo \& S. Akino, (Eds.), 464-467, The 4th PGPR International Workshop Organizing Committee, Faculty of Agriculture, Hokkaido University, Sapporo, Japan

Standbury, P.F. \& Whitaker, A. (1984). Principles of Fermentation Technology. Oxford: Pergamon Press.

Taylor, R.J., Pasche, J.S. \& Gudmestad, N.C. (2006). Biological significance of mefenoxam resistance in Phytophthora erythroseptica and its implications for the management of pink rot of potato. Plant Disease 90: 927-934

Taylor, R.J., Salas, B., Secor, G.A., Rivera, V. \& Gudmestad, N.C. (2002). Sensitivity of North American isolates of Phytophthora erythroseptica and Pythium ultimum to mefenoxam (metalaxyl). Plant Disease 86: 797-802

USDA (1965). Losses in Agriculture, U.S. Department of Agriculture Handbook 291. U.S. Department of Agriculture, Agricultural Research Service.

Van Brunt, J. (1986). Fermentation economics. Biotechnology 4: 395-401

Wei, H.L. \& Zhang, L.Q. (2006). Quorum-sensing system influences root colonization and biological control ability in Pseudomonas fluorescens 2P24. Antonie van Leeuwenhoek, International Journal of General and Molecular Microbiology 89: 267-280

Wilson, C.L., Ghaouth, A.E., Chalutz, E., Droby, S., Stevens, C., Lu, J.Y., Khan, V. \& Arul, J. (1994). Potential of induced resistance to control postharvest diseases of fruits and vegetables. Plant Disease 78: 837-843

Wood, D.W. \& Pierson III, L.S. (1996). The phzI gene of Pseudomonas aereofaciens 30-84 is responsible for the production of a diffusible signal required for phenazine antibiotic production. Gene 168: 49-53

Woodhead, S.H., O'Leary, D.J. \& Rabatin, S.C. (1990). Discovery, development, and registration of a biocontrol agent from an industrial perspective. Canadian Journal of Plant Pathology 12: 328-331

Wu, Z., Ma, J., Wang, Y., Yang, L. \& Lou, K. (2009). Identification of salt tolerant promoting growth bacteria Rs-198 and study on co-culture with Rs-5'. Shengwu Jishu 19: 63-66 
Zhang, S., Schisler, D.A., Boehm, M.J. \& Slininger, P.J. (2005). Carbon-to-nitrogen ratio and carbon loading of production media influence freeze-drying survival and biocontrol efficacy of Cryptococcus nodaenisis OH 182.9. Phytopathology 95: 626-632

Zhang, S., Schisler, D.A., Jackson, M.A., Boehm, M.J., Slininger, P.J. \& Liu, Z. (2006). Cold shock during liquid production increases storage shelf-life of Cryptococcus nodaensis $\mathrm{OH} 192.9$ after air drying. Biocontrol Science and Technology 16: 281-293

Zhang, Z. \& Pierson III, L.S. (2001). A second quorum-sensing system regulates cell surface properties but not phenazine antibiotic production in Pseudomonas aureofaciens. Applied and Environmental Microbiology 67: 4305-4315 


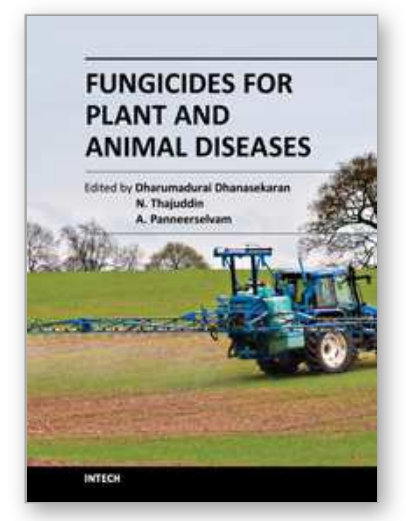

\author{
Fungicides for Plant and Animal Diseases \\ Edited by Dr. Dharumadurai Dhanasekaran
}

ISBN 978-953-307-804-5

Hard cover, 298 pages

Publisher InTech

Published online 13, January, 2012

Published in print edition January, 2012

A fungicide is a chemical pesticide compound that kills or inhibits the growth of fungi. In agriculture, fungicide is used to control fungi that threaten to destroy or compromise crops. Fungicides for Plant and Animal Diseases is a book that has been written to present the most significant advances in disciplines related to fungicides. This book comprises of 14 chapters considering the application of fungicides in the control and management of fungal diseases, which will be very helpful to the undergraduate and postgraduate students, researchers, teachers of microbiology, biotechnology, agriculture and horticulture.

\title{
How to reference
}

In order to correctly reference this scholarly work, feel free to copy and paste the following:

Patricia J. Slininger and David A. Schisler (2012). Biological Control Agents for Suppression of Post-Harvest Diseases of Potatoes: Strategies on Discovery and Development, Fungicides for Plant and Animal Diseases, Dr. Dharumadurai Dhanasekaran (Ed.), ISBN: 978-953-307-804-5, InTech, Available from: http://www.intechopen.com/books/fungicides-for-plant-and-animal-diseases/biological-control-agents-forsuppression-of-post-harvest-diseases-of-potatoes-strategies-on-discove

\section{INTECH}

open science | open minds

\section{InTech Europe}

University Campus STeP Ri Slavka Krautzeka 83/A 51000 Rijeka, Croatia Phone: +385 (51) 770447 Fax: +385 (51) 686166 www.intechopen.com

\section{InTech China}

Unit 405, Office Block, Hotel Equatorial Shanghai No.65, Yan An Road (West), Shanghai, 200040, China 中国上海市延安西路65号上海国际贵都大饭店办公楼405单元 Phone: +86-21-62489820

Fax: +86-21-62489821 
(C) 2012 The Author(s). Licensee IntechOpen. This is an open access article distributed under the terms of the Creative Commons Attribution 3.0 License, which permits unrestricted use, distribution, and reproduction in any medium, provided the original work is properly cited. 